\title{
A DISEASE OF TOMATO IN PUERTO RICO RESEMBLING THE BR.AZILIAN CURLY TOP OF TOMATOES
}

A disease of tomatoes caused by virus infection has been observed for the past several years in the Island of Puerto Rico. The disease is known locally as "tisis"; it occurs the year round. Our observations show that the field incidence of the disease fluctuates from a few cases up to 12 percent, although it usually remains very low. Infected plants are characterized by severe stunting and marked stiffening and bronzing of stem and petioles (fig. 1, A). There is a downward curling of tips and margins of the leaflets which turn yellow and remain small. Affected plants fail to produce fruits and in many cases wither and die.

Transmission experiments have shown that the disease is not transmitted by juice-inoculation methods but is readily transmitted by grafting. Experiments involving mechanical inoculation with the aid of carborundum and the addition of $\mathrm{NaSO}_{3}$ to the extracted juice have failed to reproduce the disease on the following plants: Lycopersicum esculentum $\mathrm{L}$., Cucumis sativus L., Capsicum frutescens I., Nicotiana glutinosa L., and Phaseolus vulgaris $\mathrm{L}$.

Typical symptoms were produced in about $11 / 2$ months by grafting infected tomatoes on Lycopersicum esculentum L., and Datura stramonium. D. stramonium, (fig. 1, B) grafted with diseased tomatoes showed symptoms similar to those produced on infected tomato plants. Clearing or yellowing of small veins was followed by wrinkling and downward curling of leaves. Diseased plants became stunted, but there was no bronzing of stems and petioles. Similar grafts induced no symptoms on plants of Solanum luberosum L., $N$. tabacum L., and S. nigrum L. Attempts failed to transmit the virus by means of the leafhopper Agallia albidula Uhl.

1 Cook, M. T., Ann. Rept. Agric. lixpt. Station, Río Piedras, P. R. 1935-36, 1937.

2 Deighton, F. C., Rept. Dept. Agric. S. Leone, 1935, pp. 22-6, 1936.

3 - Rept. Dept. Agric. S. I.cone, 1937, pp. 45-7, 1938. 


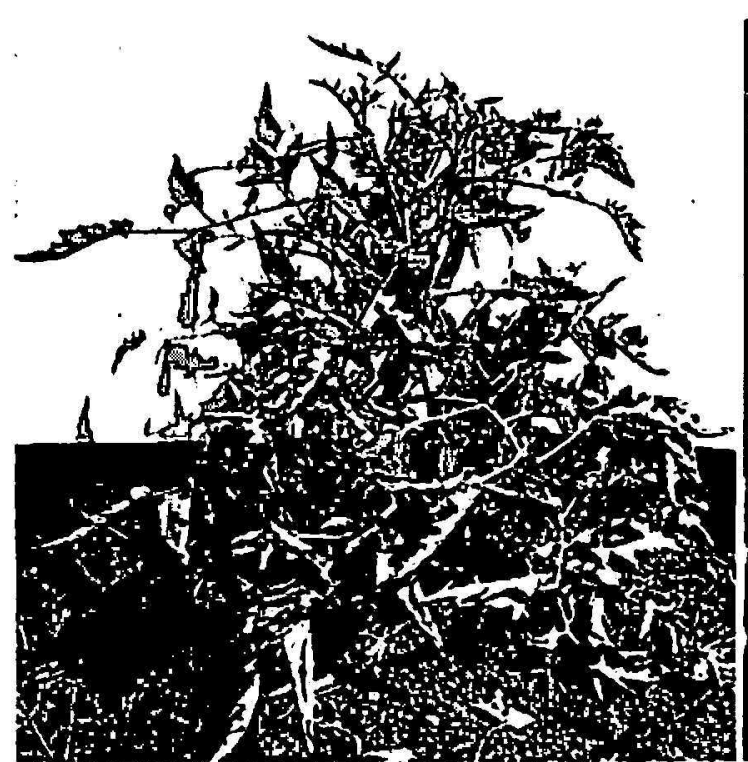

A

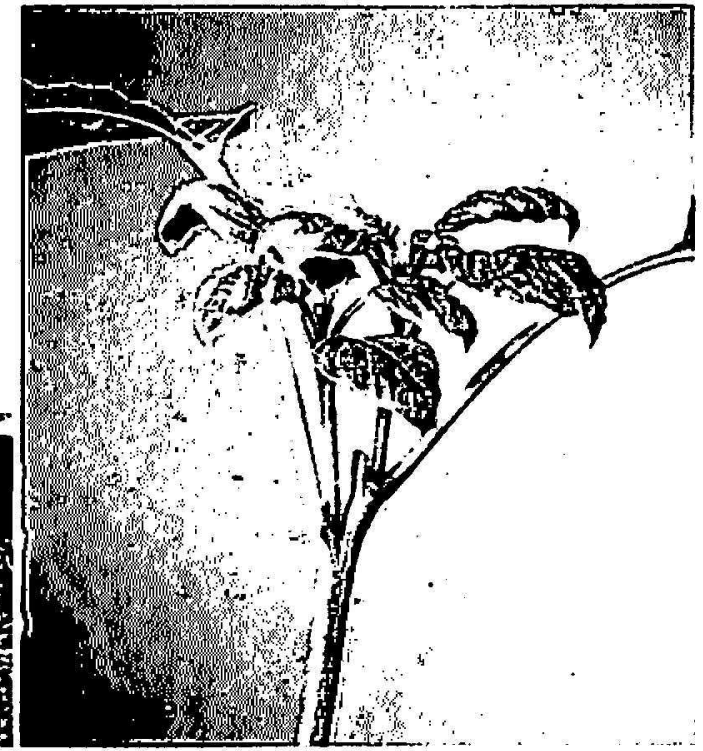

I3

Fig. 1.-Tomato plant (A) and Balura stramonium (B) showing symptoms of "tisis."

The virus occurring on tomatoes in Puerto Rico bears a striking symptomatological resemblance to the curly top viruses on tomatoes reported from Brazil' ${ }^{1}$. One of these viruses, the brasiliensis variety, is transmitted by the leafhopper, Agallia albidula Uhl., and has a wide host range. The other virus, the solanacearum variety, is transmitted by the leafhoppers Agalliana ensigera Oman and Agallia sticticollis Stahl, and its host range is much narrower.

The fact that we have not been able to transmit our virus by means of A. albidula might indicate that it is related to the solanacearum variety of curly top which is transmitted by $A$. sticticollis, as reported by Costa (2). It remains to be seen, whether $A$. sicticollis, an insect which is rarely found on tomatoes under our conditions, is also the vector of our virus. On the other hand, it is interesting to notice the resistance of S. nigrum to our tomato virus, a plant which Costa found to be one of the few hosts susceptible to the solanacearum variety of Brazilian curly top. Therefore, whether the "tisis" of tomato in Puerto Rico is related to varieties of tomato curly top found in Brazil cannot be determined definitely until further studies are made.

\section{José Adsur \\ Department of Plant Pathology}

' Bennett, C. W., and Costa, A.S., The Brazilian curly top of tomato and tobacco resembling North American and Argentine curly top of sugar beet, U.S.D.A. J. Agr. Res. 78 675-93, 1949.

2 Costa. A. S., Further studies on tomato curly top in Brazil, Phytopath. 42 396-403, 1952. 